\title{
Lifestyles of Populations of Extractive Reserves of Rondônia - Brazil
}

\author{
Rogério Delbone Haddad ${ }^{1,2,3}$, Rubens Riscala Madi ${ }^{2,3}$, Andressa Sales Coelho ${ }^{2,3}$ \\ ${ }^{1}$ Federal Institute of Education, Science and Technology of Rondônia, Brazil \\ ${ }^{2}$ Tiradentes University, Aracaju, Sergipe, Brazil \\ ${ }^{3}$ Institute of Technology and Research, Aracaju, Sergipe, Brazil \\ Correspondence: Rogério Delbone Haddad, Federal Institute of Education, Science and Technology Ariquemes, \\ Rondônia, Brazil.
}

Received: November 4, 2019

Accepted: November 26, 2019

Available online: November 27, 2019

doi:10.11114/ijsss.v8i1.4625

URL: https://doi.org/10.11114/ijsss.v8i1.4625

\begin{abstract}
Extractive Reserves (Resex) are a category of sustainable use conservation unit that aims to protect the livelihoods and culture of their populations, and ensure the sustainable use of natural resources. This article aims to analyze a set of social, economic and environmental indicators aimed at the sustainable development of the populations, protected areas and the "Extractive Reserves" located in the State of Rondônia - Brazil. This is a cross-sectional study, descriptive and analytical field study with a multi-method approach, conducted in 2017 and 2018, where the different ways of life and the dynamics in the construction of spaces of these populations were observed and experienced, of (re)consideration of individuals in environmental, social and economic policies and to form the basis for the interdisciplinary approaches, in the study indicators and in the intervention and management of the territory and its resources. The results showed that the Resex populations need a broader view of the State and Society, because their lives are, with few perspectives, one can perceive the vulnerability of many in relation to poverty, lack of basic assistance and consequently the generation of social exclusion. In this sense, the analysis of the study indicators and the interconnections with authors on the socio-environmental and economic scenarios of the Amazon identified that the Resex public policies need to be rethought in order to build a fairer and more equitable society.
\end{abstract}

Keywords: rubber tappers, territories environment, development

\section{Introduction}

In order to ensure biodiversity conservation and environmental and economic sustainability, the constitution of Extractive Reserves was an important milestone for the recognition of forest peoples (Extractivists). However, the historical way of this type of conservation unit thought and idealized by the State brings in its genesis the preservationist ideology, legitimizing the "modern myth of untouched nature" (Diegues, 2004).

Extractive Reserves are a category of sustainable use conservation units whose general objective is to protect the livelihoods and culture of their populations, and to ensure the sustainable use of natural resources (Snuc/9.985) (Brazil, 2000).

In 1989, the Extractive Reserves were legitimized, within the scope of the National Environmental Policy, enabling their creation from Law 7,804/1989, and their regulation through Decree 98,897/1990 (Brazil/1990). According to this legislation, the institution responsible for the creation and management of federal Reserves was the Brazilian Institute of Environment and Renewable Natural Resources (IBAMA). In 2007, from the division of IBAMA and the creation of the Chico Mendes Institute for Biodiversity Conservation (ICMBio), it became the body responsible for federal conservation units (Law No. 11.516/2007) (Brazil, 2007).

Alegretti (1990) describes that Extractive Reserves were created as a result of the struggles of the Amazon rubber tappers, aiming at guaranteeing their life forms and economic and cultural autonomy, by guaranteeing the possession of land and the use of traditional methods, the protection of individual property rights supported and monitored by the State, ensuring better human life conditions.

The recognition of the rights of the populations of the Extractive Reserves, even if it signifies an openness to reality divided into antagonistic principles between the environment and culture, it has nonetheless brought certain limitations to these populations, as their ways of life must be in line with a model of sustainable living (Medeiros, R.; Irving, M.A; 
Garay, I. 2006).

In fact, the concept of environment is complex and is constituted by the presence of natural and human elements that are interrelated and economically conditioned, reproducing heterogeneous social relations from their class, spatial and social character (Medeiros, R. ; Irving, M.A; Garay, I. 2006)

Because Sen (2000) states that insofar as development is concerned with the achievement of a better life, the focus of the analysis should include the nature of people's lives and, therefore, it is necessary to incorporate elements that allow the assessment of quality. beyond those commonly used which offer purely quantitative measures. From this perspective, the author highlights development in all its important dimensions, rather than restricting it to some of the interrelated means that play a relevant role in this process.

Thus development requires the removal of major forms of deprivation of liberty such as poverty and tyranny, lack of economic opportunity and systematic social destitution, neglect of public services, and intolerance or excessive interference of repressive states,

"It is undeniable that social opportunities facilitate economic participation, in this regard, it cannot be forgotten that among the essential functions of the so-called social states is the attempt to equalize the starting points in order to achieve equal opportunities between the members of society that effectively promote the free development of the individual. And in this respect, the promotion of health and education rights are paramount and play a strategic role in shaping the social development of the population, with repercussions also on the economic expansion in its entirety." (Sen, 2010, p.26, our translation ${ }^{1}$ ).

In this perspective Sachs (2015) "The Age of Sustainable Development", sustainable development is, beyond an idea, a reference today is a way of understanding the world and a method of solving global problems. The Sustainable Development Goals must provide "socially inclusive and environmentally sustainable economic growth". To achieve these economic, social and environmental objectives, good governance must be present.

The normative perspective of sustainable development contributes to the preservation of the environment, the approach to development means that the good society is not only economically prosperous, but also inclusive, environmentally sustainable and efficiently managed.

Carvalho and Frazão-Moreira (2011) recognize the indivisibility between the social and the natural, in a perspective that emphasizes social agents and the integrated nature of protected areas as products of life, consumption and contemplation of the people of the Amazon rainforest.

In this context, it is considered to protect the vulnerable population of these locations by showing the importance of Extractive Reserves and their populations, as regards to their struggles, identities, trajectories and dynamics in the construction of their role as guardians of the Amazon Rainforest, since often are unnoticed about the gaze of society and the state.

The objective of this research was to analyze a set of social, economic and environmental information focused on sustainable development of the populations of the Amazon Extractive Reserves.

\section{Material and Methods}

This is a cross-sectional study, descriptive and analytical field study with a multi-method approach, conducted in 2017 and 2018, where the different ways of life and the dynamics in the construction of spaces of these populations were observed and experienced, of (re)consideration of individuals in environmental, social and economic policies and to form the basis for the interdisciplinary approaches, in the study indicators, in the intervention, in the management of the territory and its resources.

In this context, four conservation units were selected for the development of the study because they are managed by the Chico Mendes Institute for Biodiversity Conservation:

Resex Ouro Preto River was one of the first four Extractive Reserves created in Brazil in 1990. It has 204,631.55 hectares and it is located in the extreme west of the state of Rondônia, in the municipalities of Guajará-Mirim and Nova Mamoré. It is surrounded by other protected areas, except for its northwestern limit, where it faces agricultural and livestock properties. Limited to the north with the Indigenous Land Lage and Guajará-Mirim State Park, south and west with the State Biological Reserve of Ouro Preto River, State of Pacaás Novos Extractive Reserve, and to the east with the Indigenous Land Uru- I- Wau-Wau (ICMbio, 2018). (Table 1; Figure 1).

Resex Cuniã Lake was created in 1999 and has 50,603.84 hectares and it is located in Porto Velho. It lies on the left

\footnotetext{
${ }^{1}$ All quotations have been translated by the authors of this text.
} 
(west) bank of Madeira River, to the east it borders the Cuniã Ecological Station, to the south it borders the districts of São Carlos and Terra Caída, north with the State Sustained Income Forest (ICMbio , 2018).(Table 1; Figure 1).

Resex Cautário River was created in 2001, it has 75,124.93 hectares, and it is located in the municipality of Guajará-Mirim. It is inserted in a mosaic of conservation units and Indigenous Lands that surround it in all its borders, the Resex Cautário River State (to the east and south), Serra da Cutia National Park (to the west), Uru-Eu- Wau-Wau (north) (ICMbio, 2018) (Table 1; Figure 1).

Resex Barreiro das Antas, was established in 2001, it has 106,197.74 hectares, and it is located in the municipality of Guajará-Mirim, bordering the north with the Pacaás Novos River State Resex, to the east and south with the Serra da Cutia National Park and to the west with the Pacaás Novas Indigenous Land and the Traçadal State Biological Reserve (ICMbio, 2018). (Table 1; Map 1).

Table 1. Area, population, municipality and year of creation of the Federal Extractive Reserves studied in the State of Rondônia

\begin{tabular}{lccclc}
\hline Name & Hectares & Families & Population & \multicolumn{1}{c}{ County } & \multicolumn{1}{c}{ Year/Creation } \\
\hline Resex Ouro Preto River & $204,631.55$ & 157 & 583 & $\begin{array}{l}\text { Guajará-Mirim and Nova } \\
\text { Mamoré }\end{array}$ & 1990 \\
\hline Resex Cuniã Lake & $50,603.84$ & 100 & 273 & Porto Velho & 1999 \\
\hline Resex Cautário River & $75,124.93$ & 11 & 22 & Guajará-Mirim & 2001 \\
\hline Resex Barreiro das Antas & $106,197.74$ & 12 & 40 & Guajará-Mirim & 2001 \\
\hline
\end{tabular}

Source: ICMBIO 2016

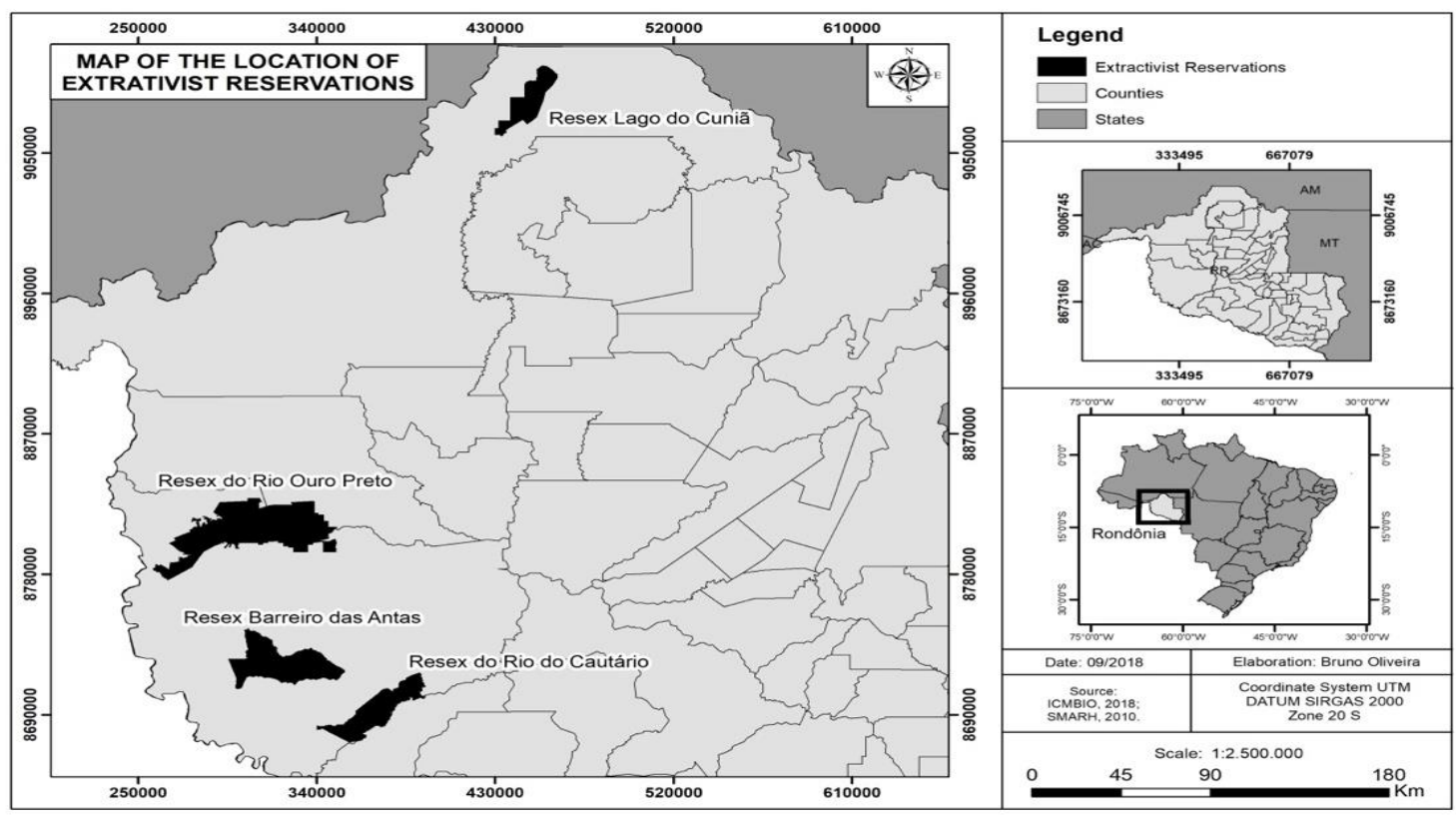

Map 01. Location of the four Federal Extractive Reserves studied in the State of Rondônia

Source: ICMBIO, 2018: SMARH 2010.

The territorial space described was the scenario defined for the research, in spite of its limits, this informative set served as subsidiary data of the analytical work, since such information represents essential elements that can visualize the conditions in which these Reserves are inserted.

The sample for the population of rubber tappers was made by the Barbetta Formula, that aims to fragment a representative sample of this universe, being: $n o=1 / \mathrm{E}_{0}^{2}$, where $\mathrm{n}=\left(\mathrm{N} \mathrm{x} \mathrm{n} \mathrm{n}_{0}\right) /\left(\mathrm{N}+\mathrm{n}_{0}\right)$ where $\mathrm{N}=$ population size; $\mathrm{n}_{0}=1$ st approximation of the sample size; $\mathrm{E}_{0}=$ tolerated sampling error and $\mathrm{N}=$ sample size, having as sampling error parameters 0,05 (Barbetta, 2010). Confidence Intervals (CI) at $95 \%$ were calculated for all estimates (Table 2). 
Table 2. Extractive Reserves and sample calculation for families (Barbetta, 2010)

\begin{tabular}{cc}
\hline Name of the Reserve & Sample Calculation \\
\hline Ouro Preto River Extractive Reserve & $\mathrm{n}=157 \times 400 / 157+400=113$ families \\
\hline Cuniã Lake Extractive Reserve & $\mathrm{n}=100 \times 400 / 100+400=80$ families \\
\hline Cautário River Extractive Reserve & $\mathrm{n}=11 \times 400 / 11+400=11$ families \\
\hline Extractive Reserve Barreiro das Antas & $\mathrm{n}=12 \times 400 / 12+400=12$ families
\end{tabular}

Source: ICMBIO 2016

From the calculated sample, the instruments that best evidenced the results were selected, the following were used: socioeconomic questionnaires for each household representative, interviews were conducted with families, representatives of associations and cooperatives, and managers of protected areas.

Data collection was carried out in two stages: the first in 2017 at Resex Cautário River and Cuniã Lake and the second in 2018 at Resex Ouro Preto River and Barreiro das Antas. This procedure was adopted due to factors such as logistics, scheduling, authorizations and availability of ICMbio servants for follow-up.

A total of 155 families participated in the survey who answered the socioeconomic questionnaire distributed according to the sample by the four Extractive Reserves in the State of Rondônia, of these 52\% $(\mathrm{n}=80)$ of the Ouro Preto River Reserve, 40\% ( $\mathrm{n}=62)$ of the Cuniã lake Reserve, $7 \%(\mathrm{n}=11)$ of the Cautário River Reserve and 1\% ( $\mathrm{n}=2)$ of the Barreiro das Antas Reserve.

Interviews were conducted to 20 families at Resex Ouro Preto River, 15 families at Resex Cuniã Lake, 11 families at Resex Cautário River and 2 families at Resex Barreiro das Antas.Regarding attendance to meetings (deliberative and consultative), six meetings were respectively followed at Resex Ouro Preto River, four at Resex Cuniã Lake, four at Resex Cautário River and three at Resex Barreiro das Antas, always with the participation of unit managers who are Federal Government employees, linked to the Chico Mendes Institute for Biodiversity Conservation, responsible for the technical and administrative support and support of the reserves..

After applying the socioeconomic questionnaire and interviews, the nominal and ordinal qualitative variables used in the research were transcribed.

A univariate descriptive analysis was performed, and the extracted data were categorized by obtaining the respective frequencies and percentages, presented as graphs and tables. An inferential analysis was performed by crossing the variables of general household characteristics and the monthly economic income. To verify the association between qualitative variables and groups, the Chi-square test $\left(\chi^{2}\right)$ (Pearson, 1992), when the observed frequency was less than 5 , Fisher's exact test was used (Fisher, 1922).

For crossings between the quantitative (economic income) and qualitative variables, the normality of distribution of this variable (economic income) was initially verified by the Shapiro-Wilk test (Shapiro; Wilk, 1965) $(p-v a l u e=0.05)$. Since no normality was observed ( $\mathrm{p}$-value $<0.05$ ), nonparametric tests were adopted for the analysis. For the crossing of variables with more than two categories, Kruskal-Wallis (Kruskal; Wallis, 1952), and for the variables with two categories, the Mann-Whitney test (Mann; Whitney, 1947) was chosen.

In all, a significance level of 5\% was adopted and the software used was R, version 3.4.2 (The R Core Team, 2017).

For the analysis of qualitative data obtained through interviews, observation and participation in meetings in the Reserves (communities and managers) we used content analysis (Bardin, 2009), which is based on interpretations, observations and categorization of the transcribed dialogues. According to Costa (2001), the main objective of content analysis is interpretation, because interpreting is related to discovering meanings and how to understand them, and how the meanings of things can be thought of in many different ways, always mediated by language. In this sense Galiazzi (2003), describes that the analyzes and descriptions of the contents are based on a critical reading, which seeks a comprehensive explanation, so that the research contributes better in relation to the results.

The research was submitted and approved by the Research Ethics Committee of the Tiradentes University (UNIT), under Opinion number 2.061.035/2017.

\section{Results and Discussion}

The variables "age", "gender of heads of households", "literacy" and "race/color" show the participants' profile (Table 3). This scenario helped identifying the best ways to approach in their way of life in order to understand and identify the dynamics of the economic and social issues of families and communities. 
Table 3. Age, gender, race and literacy data of the Cautário River, Ouro Preto River, Barreiro das Antas and Cuniã Lake Extractive Reserves - 2017/2018

\begin{tabular}{|c|c|c|}
\hline Variables & Categories & Frequency $(\mathbf{N})$ \\
\hline \multirow[t]{8}{*}{ Age } & 18 to 30 years old & $14.19 \%(22)$ \\
\hline & 31 to 40 years old & $35.48 \%(55)$ \\
\hline & 41 to 50 years old & $22.58 \%(35)$ \\
\hline & 51 to 60 years old & $14.84 \%(23)$ \\
\hline & 61 to 70 years old & $10.97 \%(17)$ \\
\hline & 70 years or older & $1.94 \%(03)$ \\
\hline & Average & 43.45 \\
\hline & $\mathrm{SD}$ & 12.36 \\
\hline \multirow[t]{2}{*}{ Gender } & Female & $25.16 \%(39)$ \\
\hline & Male & $74.84 \%(116)$ \\
\hline \multirow[t]{2}{*}{ Literacy } & Yes & $83.87 \%(130)$ \\
\hline & Not & $16.13 \%(25)$ \\
\hline \multirow[t]{4}{*}{ Race/Color } & White & $28.39 \%(44)$ \\
\hline & Black & $4.52 \%(07)$ \\
\hline & Brown & $65.15 \%(101)$ \\
\hline & Yellow & $1.93 \%(03)$ \\
\hline
\end{tabular}

Regarding race/color, the majority of respondents declared themselves brown and literate. It was identified during the interviews that among the non-literate participants the largest number were people above 50 years old (who only sign their names), and according to the testimonials they did not have the opportunity to go to school as children.

Extractive Reserves represent a milestone in the history of biodiversity conservation in the country, innovating because they were created "from the bottom up", that is, from organized social movements, and also based on the differential characteristics of extractive populations. Amazonian ecosystems, in order to articulate the environmental and land tenure dimensions (Almeida, 2003; Cunha, 2002; Millikan, 1994).

The analysis of monthly income identified that most families survive on incomes of up to one minimum wage, making it difficult to access health care, medicines, basic purchases and often boat/fly rentals to travel to the city (Table 4). The production of the Resex surveyed is quite diversified, Resex Cautário River and Barreiro das Antas have as main production Brazil nuts, Ouro Preto River cassava flour and Cuniã Lake alligator management (Table 4).

Table 4. Monthly income and means of production of Resex Cautário River, Barreiro das Antas, Cuniã Lake and Ouro Preto River - Period: 2017/2018.

\begin{tabular}{|c|c|c|}
\hline Variables & & \\
\hline $\begin{array}{ll}\text { Monthly income } \\
\end{array}$ & \multicolumn{2}{|c|}{ Frequency (N) } \\
\hline Families with income up to 1 minimum wage & \multicolumn{2}{|c|}{$78.06 \%(121)$} \\
\hline Families with income between 1 and 2 times the minimum wage & \multicolumn{2}{|c|}{$19.36 \%(30)$} \\
\hline Families with income between 3 and 4 times the minimum wage & \multicolumn{2}{|c|}{$2.58 \%(4)$} \\
\hline $\begin{array}{c}\text { Average } \\
\text { SD } \\
\end{array}$ & \multicolumn{2}{|c|}{$\begin{array}{c}878.04 \\
453\end{array}$} \\
\hline Production & Main & Secondary \\
\hline Acai berry & $1.3 \%(2)$ & $11.84 \%(18)$ \\
\hline INSS Beneficiary & $10.32 \%(16)$ & $1.97 \%(3)$ \\
\hline Nuts & $12.90 \%(20)$ & $50.0 \%(76)$ \\
\hline Copaiba & $0.65 \%(1)$ & $1.97 \%(3)$ \\
\hline Cassava flour & $30.32 \%(47)$ & $10.53 \%(16)$ \\
\hline Alligator Management & $37.42 \%(58)$ & $1.32 \%(2)$ \\
\hline Cassava & $0.65 \%(1)$ & \\
\hline Corn & $0.65 \%(1)$ & \\
\hline Rubber Tree & $2.58 \%(4)$ & $21.05 \%(32)$ \\
\hline Public servant & $3.23 \%(5)$ & \\
\hline
\end{tabular}

Families residing in the communities that make up the Ouro Preto River Reserve have been showing favorable results. One of the main improvement factors is the participation in associations and cooperatives in Resex, which work by providing technical support in production, marketing and thus contributing to the development, purchasing power of families and consequently better living conditions. 
The resident families of the Barreiro das Antas Reserve had higher income, due to the small number of inhabitants and have social security benefit. The current problem is the emptying and isolation of the unit, as stated by the unit manager (personal communication on 05/20/2018). Also according to the manager actions are being taken to encourage the return of several families who abandoned their placements and migrated to the city.

The Cautário River Reserve has the lowest average income, and it is possible to identify conflicts of interest, management and organization as a community, problems that contribute to lower purchasing power of families. During the interviews, it was observed in the statements of extractivists the lack of health care, basic sanitation, difficult access to school, situations that contribute to the emptying and impoverishment of the population.

In the Cuniã Lake Reserve it was possible to identify, through interviews, questionnaires and observations, that participatory and integrated management of communities and their inhabitants - especially the production from alligator management and other forest products - it has shown that the local economy has been improving people's lives in many ways, such as education, health, housing and sanitation.

Overall it was observed that families with five or more people in the household have a higher income probably due to the higher number of people working in the forest.

The extraction of forest products is the main form of subsistence in the Reserves, corroborating the objective of this category of Conservation Unit (Table 4).

According to Brown and Rosendo (2000), there are several limits to the efficiency of Resex based on their objectives. In extractive Reserves the success of populations depends on local empowerment, overcoming problems, partnerships that allow the rule of commutation, redistribution of rights and responsibilities. Still according to the authors, the Resex only achieve viability in practice, when they ensure sustainable livelihoods for forest dwellers, with higher incomes and access to social services such as health and education.

Goeschl and Igliori (2006) describe that policymakers still have the challenge of addressing the fundamental contradiction between the static nature of property rights and the economic dynamics of competition in markets where Resex tends to operate. In this perspective, environmental conservation and social development were not an alliance because the social and environmental exhaustion promoted by government intervention did not respect Resex protagonists (rubber tappers) in the Amazon (Freitas; Rivas, 2014).

The variables "Reserve", "number of people per household" and "main source of income" showed significant differences in relation to "family income", thus, there is a relationship between these variables and family income ( $<<0.0001$, Table $5)$.

In a critique of the ecosystem approach, Emilio Moran (2006) indicates several of its limitations, called oppression in the demarcation of what to encompass in a system. On the other hand, thinking in terms of a very current conceptualization made in the environment of the so-called theory of economics of biodiversity and ecosystems, ecosystem services (the benefits to communities) have to be analyzed across scales by their dynamic, global and interlocal qualities, which can also be seen in table 5 .

From this perspective, Ostrom (2001) sought to express that a set of commons destined for several individuals is not inexorable for scarcity, waste and mismanagement by its users, and that privatization or regulation by external entities is not the same. alternatives or the most efficient solutions for sustainable management. She developed the Common Pool Resource theory from case-specific studies, listing the empirical experiences of successful populations in managing common resources.

Table 5. Relationship between household income (in Brazilian Reais) and general household characteristics of Resex Cautário River, Cuniã Lake, Barreiro das Antas and Ouro Preto River (2017/2018)

\begin{tabular}{|c|c|c|c|c|c|c|}
\hline \multirow[b]{2}{*}{ Variable } & \multicolumn{5}{|c|}{ General information } & \multirow[b]{2}{*}{ P-value } \\
\hline & Average & SD* & Median & Minimum & Maximum & \\
\hline \multicolumn{7}{|l|}{ Reserve } \\
\hline Cautário River & 618.18 & 313.27 & 500 & 250 & 1100 & 0.000 \\
\hline Cuniã Lake & 766.13 & 426.94 & 600 & 500 & 3000 & \\
\hline Barreiro das Antas & 1500.00 & 989.95 & 1500 & 800 & 2200 & \\
\hline Ouro Preto River & 984.95 & 443.25 & 900 & 300 & 3000 & \\
\hline \multicolumn{7}{|l|}{ House Type } \\
\hline Masonry & 826.09 & 542.06 & 600 & 500 & 3000 & 0.121 \\
\hline Wood & 889.28 & 440.18 & 800 & 250 & 3000 & \\
\hline \multicolumn{7}{|c|}{ Sewage in the bathroom or sanitary } \\
\hline Rudimentary Pit & 977.57 & 397.28 & 950 & 500 & 2200 & 0.114 \\
\hline
\end{tabular}




\begin{tabular}{|c|c|c|c|c|c|c|}
\hline Septic tank & 856.99 & 467.68 & 800 & 250 & 3000 & \\
\hline Other & 800.00 & 282.84 & 800 & 600 & 1000 & \\
\hline \multicolumn{7}{|l|}{ Water supply } \\
\hline Well or spring in the Reserve & 919.37 & 485.40 & 800 & 250 & 3000 & \multirow[t]{3}{*}{0.077} \\
\hline General Suply network & 719.05 & 258.11 & 600 & 500 & 1500 & \\
\hline River & 834.77 & 424.36 & 800 & 300 & 2200 & \\
\hline \multicolumn{7}{|l|}{ Electricity } \\
\hline Not & 861.68 & 307.14 & 900 & 250 & 1854 & \multirow[t]{2}{*}{0.086} \\
\hline Yes & 893.38 & 560.17 & 700 & 500 & 3000 & \\
\hline \multicolumn{7}{|l|}{ Number of people } \\
\hline Up to 2 & 718.69 & 420.05 & 600 & 250 & 2200 & \multirow[t]{3}{*}{0.000} \\
\hline 3 to 4 & 859.45 & 388.62 & 800 & 300 & 3000 & \\
\hline 5 or more & 1064.92 & 553.43 & 1000 & 400 & 3000 & \\
\hline \multicolumn{7}{|c|}{ Gender of the Responsible ones } \\
\hline Female & 883.77 & 295.24 & 800 & 300 & 1652 & \multirow[t]{2}{*}{0.130} \\
\hline Male & 876.11 & 497.77 & 750 & 250 & 3000 & \\
\hline \multicolumn{7}{|l|}{ Main source of income } \\
\hline Extractivism & 834.88 & 355.39 & 800 & 250 & 2957 & \multirow[t]{3}{*}{0.000} \\
\hline Benefit & 1384.06 & 336.60 & 1200 & 957 & 2200 & \\
\hline Management & 672.41 & 188.99 & 600 & 500 & 1200 & \\
\hline \multicolumn{7}{|l|}{ Literacy } \\
\hline Not & 1015.72 & 740.21 & 800 & 250 & 3000 & \multirow[t]{2}{*}{0.912} \\
\hline Yes & 851.56 & 374.52 & 800 & 300 & 3000 & \\
\hline \multicolumn{7}{|l|}{ Patients in the last year } \\
\hline Not & 895.59 & 491.80 & 800 & 300 & 3000 & \multirow[t]{2}{*}{0.956} \\
\hline Yes & 829.24 & 329.57 & 800 & 250 & 1657 & \\
\hline
\end{tabular}

* Standard deviation.

Dollar: December, 2017: \$3,31

Dollar in December, 2018: \$3,81

The socioenvironmental scenario of the Reserves is a challenge for the public agenda, specifically for the balance between economic viability and the political, ecological and social sustainability of the region (Santos, 2015).

According to Diás and Cattani (2004) the growth supported by the model of development systematized by globalization showed social and economic advances to the detriment of several sectors, but others were stagnant, such as those where reality was marked by contradictory transformations, especially in relation to social and environmental issues, where the lack of basic structure for Extractive Reserve populations was limited resulting in a growing index of social inequality.

Salama (2008, p. 39) highlights that growth is not equanimous from the perspective of distributive observation and understanding, but contributes to the growth of inequalities, or decreases them, according to the conduction of legitimate growth. The author points out that growth is not regular and the evolution of poverty does not vary in the same way as gross domestic product. Thus, measuring the effects of growth on poverty from inequality variations makes it possible to realize that the poverty rate decreases less, because inequalities increase, showing impoverishing growth (Salama, 2008).

In this sense, the realization of the need for assertive policies for development requires debates in which decision making increasingly requires the participation of the communities involved. This is verified when one observes that today the tools of intervention in the territory, contradictorily, are reflections of a development project implemented by the state itself in the region disconnected with social participation, but gradually attuned to the logic of accumulation of the current capitalist mode of production. (Becker, 2004).

Augusto and Mertens (2018, p.20), in turn, consider that "although there are significant conceptual and methodological advances, there is still a great lack of concrete actions of social and environmental policies that are guided by integrative and systemic approaches". It is observed, then, that for over a decade researchers have shown limitations and/or deficiencies in the public sphere for the resolution of these impasses, and that It also highlights this situation in the Resex, during interviews, observations and participation in meetings during the field research conducted in 2017 and 2018.

Faleiros (2003) considers that the overcoming of poverty results, therefore, the definition of a position and a strategic action of the State and State in priority defense of reduction of social injustices, using as an instrument the inclusion of opportunities, as the possibility of development of policies aimed at the sustainable development of the Resex populations, in order to reduce economic and social problems, such as health and education, in order to reduce their social vulnerability.

The Amazon, because it is a huge universe of resources and so little explored by traditional populations that enjoy very little of what is extracted from these lands by capitalism, continues to seize resources without giving this people the 
opportunity to reduce the rate of inequality that is so close to the world. all of the impoverishment index (Neves, 1989). According to the author, for three decades, the same problems continue to echo these days, and with a much greater demand for the exclusion and impoverishment of the Amazonian people.

Another relevant aspect refers to the conflicts evidenced from different perspectives regarding the importance and the sense of conservation, protection, environment, biodiversity, landscape, agriculture, development and wildlife. Issues that among others are inevitably part of the social life of protected areas in the Amazon as anthropocentric and anthropomorphized territories (Knight, 2005; Milton, 2005).

Planners and policy makers need to consider the potential effects of planned development on the Amazon rainforest, based on evidence compiled from studies based on ecological economics (Ostron and Tucker, 2009). Thus the need for economic policies aimed at the economic viability of the Resex will be equal and efficient if there is investment in less complex production processes and chains aimed at traditional populations, not always viable (Negret, 2010). And in this perspective during the research data showing the need for these policies to be rethought with the involvement of the population were observed and obtained.

As much as Resex's environmental policy is unique throughout Brazil, social, economic, environmental and cultural realities are heterogeneous and marked by local characteristics (Florentino; Silva; Freitas, 2016).

\section{Conclusion}

The places, the environment, the landscape, as sociocultural structures obtained lived and felt, elaborated on the territory and on the world present a social and cultural adequacy of the spaces. Protected areas (Extractive Reserves) should be looked upon as products of a historical, political and economic process of socio-spatial formation.

The diversity of the complexity of interlocutors and their different points of view, as well as the growing miscegenation of knowledge and learning make us look at Extractive Reserves as dynamic and constantly changing public arenas, because sustainable use conservation units are dynamic realities lived and managed by individuals and yet connected by abiotic elements.

They speak not only of possibilities of knowledge but also of balance, of forms of territorial and social intervention that tend to antagonize or underestimate individuals as oppressive agents of nature and biodiversity. However, the truth is that the forest peoples are central elements in the extractive Reserves and are also builders of biodiversity, contributing to the preservation and conservation of traditional Amazonian communities.

In this sense, this research highlights the need for greater support from the State and society to these populations, in order to rethink ways of survival of poor and excluded people, who without basic conditions of survival, often leave their homes, their history and venture to migrate to cities in search of better living conditions, depleting the forest, losing their identities and leaving the Amazon biome more isolated, abandoned and vulnerable to unsustainable exploitation.

\section{Acknowledgements}

To the Graduate Program in Health and Environment of the Tiradentes University (Unit), the Tropical Biology Laboratory of the Institute of Technology and Research (ITP), the Federal Institute of Education, Science and Technology of Rondônia Coordination for the Improvement of Higher Education Personnel (CAPES), to the managers and population of the Extractive Reserves surveyed.

\section{References}

Allegretti, M. H. (1990). Extractive reserves: an alternative for reconciling development and environmental conservation in Amazonia. In A. Anderson (Ed.), Alternatives for deforestation: steps toward sustainable use of the Amazon rain forest. Nova York, Columbia University Press, pp. 252-264.

Almeida, M. W. B. (2003). A Luta dos Seringueiros na Amazônia. In: Seminário ANPOCS. Mesa redonda sobre Amazonas. Caxambu. Caderno de Resumos ANPOCS.

Augusto, L., Giraldo, da S., \& Mertens, F. (2018). Abordagens ecossistêmicas em saúde, ambiente e sustentabilidade: avanços e perspectivas. Sustentabilidade em Debate, Brasília, 9(1), 16-22, abril. https://doi.org/10.18472/SustDeb.v9n1.2018.29743

Barbetta, P. A. (2010). Estatística aplicada ciência sociais (7th ed.). UFSC.

Brasil. Constituição. (1988). Constituição da República Federativa do Brasil. Brasília: Câmara dos Deputados.

Brasil. Lei Federal no 9.795 de 27/04/1999 (1999) Institui a Política Nacional de Educação ambiental. Diário Oficial da União. Brasília: Gráfica do Senado.

Brasil. Lei Federal n ${ }^{\circ} 9.985$ de 18/07/2000. (2000). Institui o Sistema Nacional de Unidades de Conservação da Natureza 
(SNUC). Diário Oficial da União DE 19/7/2000. Brasília: Gráfica do Senado.

Brasil. Lei Federal n ${ }^{\circ}$ 11.516, de 28 de agosto de 2007. (2007). Dispõe sobre a criação do Instituto Chico Mendes de Conservação da Biodiversidade - Instituto Chico Mendes.

Bardin. L. (2009) Análise de Conteúdo. Tradução de Luís Antero Reto e Augusto Pinheiro. Edições 70. Lisboa: Persona.

Becker, B. K. (2004). Amazônia. Geopolítica na Virada do III Milênio. Rio de Janeiro: Editora Garamond.

Brown, K., \& Rosendo, S. (2000). Environmentalists, rubber tappers and empowerment: the political and economic dimensions of extractive reserves. Development and Change, 31, 201-227. https://doi.org/10.1111/1467-7660.00152

Carvalho, A. M., \& Frazão-Moreira, A. (2011). Importance of local knowledge in plant resources management and conservation in two protected areas from Trás-os-Montes, Portugal. Journal of Ethnobiology and Ethnomedicine. https://doi.org/10.1186/1746-4269-7-36

Conselho Nacional Dos Seringueiros. (1993). Poronga. Comunicação e Editoração Ltda. Diretrizes para um programa de Reservas Extrativistas na Amazônia. Rio Branco. 52p.

Costa, Alexandre Araújo. (2001). Introdução ao direito. Porto Alegre: Sergio Antonio Fabris Editor.

Cunha, L. H. (2002). Reservas Extrativistas: Uma Alternativa de Produção e Conservação de Biodiversidade. NUPAUB - USP. São Paulo.

Días, M., Laura, E. C., \& Antonio, D. (2004). Desigualdad, pobreza, exclusión y vulnerabilidad en América Latina. México, AUEM / ALAS/ UFRGS.

Diegues, A. C. S. (2004). O mito moderno da natureza intocada (5th ed.). São Paulo: Hucitec; NUPAUB.

Faleiro, S. V. de P. (2003). Fome, pobreza e exclusão social: desafios para o governo e a sociedade. Ser Social: Revista do Programa de Pós Graduação em Política Social do Departamento de Serviço Social da Universidade de Brasília. Vol.1, n.1. Brasília: UNB.

Fischer, M. (1985). Da antropologia interpretativa à antropologia crítica'. Anuário Antropológico/83. 55-72.

Florentino, G., Silva, D., \& Freitas, J. (2016). Análise de Reservas Extrativistas a partir da economia ecológica. Observatorio de La Economía Latinoamericana, Málaga, 16, 2-10.

Freitas, J., Silva, D., \& Rodrigues, M. (2016). Areas protegidas en el Amazon: un análisis institucional extractiva reserva el Alto Jurua. Contribuciones a Las Ciencias Sociales, Málaga, 6, 1-13.

Galiazzi, M. C. (2003). Educar pela pesquisa: ambiente de formação de professores de Ciências. Ijuí: Ed. Unijuí.

Goeschl, T., \& Igliori, D. C. (2004). Reconciling Conservation and Development: a dynamic hotelling model of extractive reserves. Land Economics, Madison, 80(3), 340-354. https://doi.org/10.2307/3654725

Hall, A. (2004). Extractive Reserves: building natural assets in the Brazilian Amazon Political Economy Research Institute. Massachusetts, v. 74, p. 2-27. Amazôniadesenvolvimento para quem? Rio de Janeiro: Jorge Zahar. 198 p.

Ibama. Instituto Brasileiro Do Meio Ambiente e dos Recursos Naturais Renováveis. Efetividade de gestão das unidades de conservação federais do Brasil. IBAMA, WWF-Brasil. - Brasília: IBAMA, 2018.

Icmbio, Instituto Chico Mendes de Conservação da Biodiversidade. (2007). Instrução Normativa $N^{o} 01$, de 18 de setembro de 2007. Publicada no Diário Oficial da União No 182, Seção I, páginas 101 e 102, de 20/09/2007, Brasília DF.

kruskal, W. H., \& Wallis, W. A. (1952). Use of Ranks in One-Criterion Variance Analysis. Journal of the American Statistical Association, 47(260), 583-621. Taylor \& Francis Group. https://doi.org/10.1080/01621459.1952.10483441

Knight, J. (2005). Introduction. In J. Knight (Ed.), Animals in Person: Cultural Perspectives on Animal-human Intimacy. Oxford, Berg, pp. 1-13.

Mann, H. B., \& Whitney, D. R. (1947). On a Test of Whether one of Two Random Variables is Stochastically Larger than the Other. The Annals of Mathematical Statistics, 18(1), 50-60. Institute of Mathematical Statistics. https://doi.org/10.1214/aoms/1177730491

Medeiros, R., Irving, M. A., \& Garay, I. (2006). Áreas Protegidas no Brasil: interpretando o contexto histórico para pensar a Inclusão Social. In IRVING, M.A. (Org.). Áreas protegidas e inclusão social: construindo novos significados. Rio de Janeiro: Fundação Bio-Rio. p.15-40.

Mckean, M. A., \& Ostrom, E. (2001). Regimes de propriedade comum em florestas: somente uma relíquia do passado? In: Diegues, Antonio Carlos; Moreira, André de Castro C. Espaços e recursos naturais de uso comum. São Paulo: 
Napaub-USP.

Millikan, B. (1994). Levantamento Sócio - econômico da Reserva Extrativista do Rio Ouro Preto. Porto Velho, IEA, Mimeo.

Milton, K. (2005). Anthropomorphism or egomorphism? The perception of non-human persons by human ones. In J. Knight (Ed.), Animals in Person: Cultural Perspectives on Animal- -human Intimacy. Oxford, Berg, pp. 255-271.

Moran, E. (2006). Ecosystem ccology in biology and anthropology. In N. Haenn e R.R. Wilk (Eds.), The Environment in Anthropology - A Reader in Ecology, Culture and Sustainable Living, Nova Iorque. New York University Press, pp. 191-202.

Negret, J. F. (2010). Flexibilização do capital na Reserva Extrativista Chico Mendes e seu entorno: o cronômetro entrou na floresta. Sociedade \& Natureza. Uberlândia, 22(2), 373-390. https://doi.org/10.1590/S1982-45132010000200011

Neves, W. (org.) (1989). Origens, adaptações e Diversidade Biológica do Homem nativo da Amazônia. ED. MPEG.

Pearson, K. (1900). On The Criterion That A Given System Of Deviations From The Probable In The Case Of A Correlated System Of Variables Is Such That It Can Be Reasonably Supposed To Have Arisen From Random Sampling. Philosophical Magazine Series 5, 50(302), 157-175. https://doi.org/10.1080/14786440009463897

Salama, B. M. (2008). O Que É Direito E Economia. In: TIMM, Luciano. Direito E Economia. Porto Alegre: Livraria do Advogado.

Sachs, J. (2015). The age of sustainable development. New York: Columbia University Press.

Santos, F. P. (2015). Reserva Extrativista e Reserva de Desenvolvimento Sustentável, uma pequena-grande diferença. Revista GEONORTE, 6(25), 43-60.

Sen, A. (2010). Desenvolvimento como Liberdade. São Paulo, Companhia das Letras.

Simonian, L. T. L. (2015). População tradicional, Reservas Extrativistas e racionalidade estatal na Amazônia brasileira. Revista Desenvolvimento e Meio Ambiente (UFPR), 33(1), 163-175. https://doi.org/10.5380/dma.v33i0.36473

Shapiro, S. S., \& Wilk, M. B. (1965). An Analysis of Variance Test for Normality (Complete Samples). Biometrika, 52(3/4), 591-611. https://doi.org/10.1093/biomet/52.3-4.591

The R Core Team. (2017). R: A Language and Environment for Statistical Computing. Vienna, Austria: R Foundation for Statistical Computing.

Tucker, C. M., \& Ostrom, E. (2009). Pesquisa multidisciplinar relacionando instituições e transformações florestais. In: Moran, E. F.; Ostrom, E. (Orgs.). Ecossistemas florestais: Interação homem-ambiente. São Paulo: Senac/Edusp, p. 109-138.

\section{Copyrights}

Copyright for this article is retained by the author(s), with first publication rights granted to the journal.

This is an open-access article distributed under the terms and conditions of the Creative Commons Attribution license which permits unrestricted use, distribution, and reproduction in any medium, provided the original work is properly cited. 